\title{
Flower and fruit structure of the endangered species Petagnaea gussonei (Sprengel) Rauschert (Saniculoideae, Apiaceae) and implications for its reproductive biology
}

\author{
O. DE CASTRO ${ }^{1}$, P. COLOMBO ${ }^{2}$, L. GIANGUZZI ${ }^{3}, \&$ R. PERRONE ${ }^{2}$
}

${ }^{1}$ Dip Biologia, Università degli Studi di Napoli Federico II, Via Foria 223 - Orto Botanico, I-80139 Napoli, Italy;

${ }^{2}$ Dip Scienze della Terra e del Mare (DiSTeM), Università degli Studi di Palermo, Viale delle Scienze, Ed. 16, I-90128 Palermo, Italy and ${ }^{3}$ Dip Scienze Agrarie e Forestali, Università degli Studi di Palermo, Viale delle Scienze, Ed. 4, I-90128 Palermo, Italy

\begin{abstract}
Petagnaea gussonei (Apiaceae) is an endangered species endemic to the Nebrodi mountains (north-eastern Sicily). Although an increasing number of studies have been performed on this species, its reproductive biology remains poorly understood. The aim of this study was to investigate in detail the structure of the flower and the fruit of Petagnaea, and the possible implications for its breeding system and seed dispersal mechanism. Results from fieldwork, light microscopy and scanning electron microscopy suggest (1) the presence of protandrous hermaphrodite flowers; (2) geitonogamy, autogamy, and allogamy as breeding system mechanisms of $P$. gussonei, even if asexual reproduction is preferred by the plant; and (3) epizoochory and hydrochory as possible modalities of fruit dispersal.
\end{abstract}

Keywords: Anatomy, breeding system, flower, fruit, micromorphology, endemic, Petagnaea gussonei, seed dispersal, Sicily

\section{Introduction}

Over the past two centuries, the monospecific genus Petagnaea Caruel (Saniculoideae, Apiaceae) has been the focus of much botanical attention due to its morphological peculiarity (e.g., Gussone 1827; Bertoloni 1837; Baillon 1880; Caruel 1889; Drude 1898; Wolff 1913; Froebe 1964; Magin 1980). More recently, thanks also to the advancement of new technologies, this plant continues to interest botanists for its ecology, biology, phylogeny, and population genetics (Colombo et al. 1997; Gianguzzi 2002; Liu et al. 2003; Gianguzzi et al. 2004; Liu 2004; Calviño \& Downie 2007; De Castro et al. 2007; Calviño et al. 2008; De Castro et al. 2008, 2009, 2013; Kadereit et al. 2008; Scharhag \& Claßen-Bockhoff 2008; Gianguzzi 2011; Kronister 2013).

Petagnaea gussonei (Spreng.) Rauschert is a rhizomatous perennial plant endemic to the Nebrodi mountains (north-eastern Sicily) that is presently classified as an endangered species on the IUCN Red
List (Gianguzzi et al. 2004; De Castro et al. 2006; Gianguzzi \& La Mantia 2006).

Petagnaea occurs in a small number of isolated populations located in the humid and shaded margins of mountain streams or rivulets, where the species usually propagates asexually through the development of stolons (Gianguzzi et al. 2004, De Castro et al. 2006). Petagnaea is also regarded as a remnant of the Tertiary flora (Wolff 1913). Inflorescences of P. gussonei are composed of three male flowers attached to a central hermaphrodite flower. Each of the flowers can be interpreted as a highly reduced umbellule, and thus the inflorescence represents a compound umbel (Froebe 1964). Fruits are small unilocular achenes.

Several researchers have studied the morphology of the inflorescence and/or fruits of Petagnaea (e.g. Caruel 1889; Wolff 1913; Magin 1980; Scharhag \& ClaßenBockhoff 2008; Kronister 2013). However, the reproductive biology of the species is still poorly understood, and there are questions about its breeding system and mode of seed dispersal. The lack of knowledge is mainly due to the difficulty in studying this 
plant in nature (i.e. rarity and difficult habitat access). Based on genetic nuclear and chloroplast DNA data, De Castro et al. (2013) presented several hypotheses on the sexual reproduction and seed dispersal modality of P. gussonei. Briefly, the authors suggested (a) the exclusion of a high cross-rate among related specimens (inbreeding); (b) the absence of strong geitonogamy or autogamy (self-fertilization); and (c) a long-range dispersal of seeds possibly carried out by animals (such as birds).

The aim of this study was to contribute new data on micromorphology and the reproductive biology of P. gussonei, (1) by observing and collecting flowers and fruits in the field at various developmental stages and (2) by analyzing in detail the collected material using both stereo and light microscope (SM and $\mathrm{LM}$ ), and scanning electron microscopy (SEM). Here, we also discuss possible implications of the observed morphological characters on the breeding system and seed dispersal mechanism of the species.

\section{Materials and methods}

\section{Plant sampling}

About 100 samples of flowers and fruits were used in this study, derived from 20 plants, randomly collected in the field, which belonged to one of the largest populations of P. gussonei (Contrada S. Adriano) (see Gianguzzi 2011). Five flowers and fruits with all parts intact were chosen per plant. Flower ontogeny was examined from early May to middle July, with bimonthly observations, until fruit formation.

\section{Light and stereo microscopy}

Samples of flowers and fruits were dehydrated in a graded ethanol series and embedded in paraffin (Catalano 1925; Beccari \& Mazzi 1966; Colombo 2003). The preliminary fresh sections were prepared with a manual microtome (A.M.G. Diagnostic) to investigate tissue distribution and subsequently subjected to the following histochemical tests: hydrochloric fluoroglucyn for detection of lignified cells and tissues (xylem and sclerenchyma), Sudan III for suberized and cutinized tissues, and iodine iodide solution (Lugol) for starch (Catalano 1925; Johansen 1940; Jensen 1962; Colombo 2003). For permanent slides, flower samples were fixed in FAA (90\% ethanol, 5\% formalin, 5\% acetic acid) (Sass 1958), dehydrated in a graded ethanol series, stained by safranin, and then mounted in Canada balsam. Flowers were clarified according to the Fuchs' method (Fuchs 1963), avoiding the tissue maceration step in a dried oven at $60^{\circ} \mathrm{C}$, in order to better preserve the whole xylem pattern (Perrone et al. 2013). All preparations were examined and photo- graphed using a transmitted light microscope (LM) (Leica DMLS) and a stereomicroscope (SM) (Leica MZ12), while digital images were obtained by a NIKON DS-Fil camera.

\section{Scanning electron microscopy}

Flowers and fruits were observed under a Zeiss EVO LS10 scanning electron microscope (SEM). All samples were prepared according to Huttunen and Laine (1983). In particular, dehydrated flowers and fruits were mounted on aluminum stubs with double adhesive tape and coated with gold prior to observation. Electron micrographs were taken at an accelerating voltage of $15 \mathrm{kV}$ and $47-2.0 \mathrm{~K}$ magnifications. Epicuticular wax morphology was classified according to Wilkinson (1979). Anatomical terminology followed Esau (1965).

\section{Results}

Flower morphology

The dichasial inflorescence includes several (reduced) umbels, each umbel generally composed of (two)-three male flowers and one hermaphrodite sessile flower [Figures $1(\mathrm{a}, \mathrm{b})$ and $2(\mathrm{a}, \mathrm{b})$ ]. The hermaphrodite flower has the calyx tube fused to the ovary, which has ten ribs, five of which are thicker; the calyx edge is formed by five erect, lanceolate, acute, whitish teeth, each tooth having an inconspicuous midrib that is a continuation of the main ribs of the ovary. Petals are as long as the calyx or twice the sepal length $(0.898 \pm 0.851 \times$ $0.493 \pm 0.423 \mathrm{~mm}$ ) [Figure 2(c,d)], with an elongated inflexed apex, deeply grooved above and ribbed below. Stamens (five) are strongly papillose and curved inward (first 10 days of May) [Figure 2 $(\mathrm{e}, \mathrm{f})]$. The ovary is topped by a stylopodium, formed by two long, filiform styles that, at the base, enlarge into two papillose, whitish nectaries [Figure $2(\mathrm{~g}, \mathrm{~h})$ ] The male flower shows a green campanulate calyx, with long whitish teeth, five strongly papillose stamens, curved inwards similarly to those of the hermaphrodite flower. In the flowering phase (end of May-early June), staminal filaments are straightened and anthers are projected outward. In contrast to the hermaphrodite flower which loses its stamens early, stamens of male flowers mature subsequently, after which they progressively desiccate, remaining evident until after anthesis [Figure 2(i)]. Anthers are dorsifixed, intorse, and longitudinally dehiscent [Figure 3(a,b,c)]. The epigynous, unilocular ovary is originally bicarpellar, having an adaxial and abaxial carpel; the size of the adaxial carpel subsequently decreases. The ovary contains a mature ovule, while the reduced carpel encloses a rudimentary ovule. 

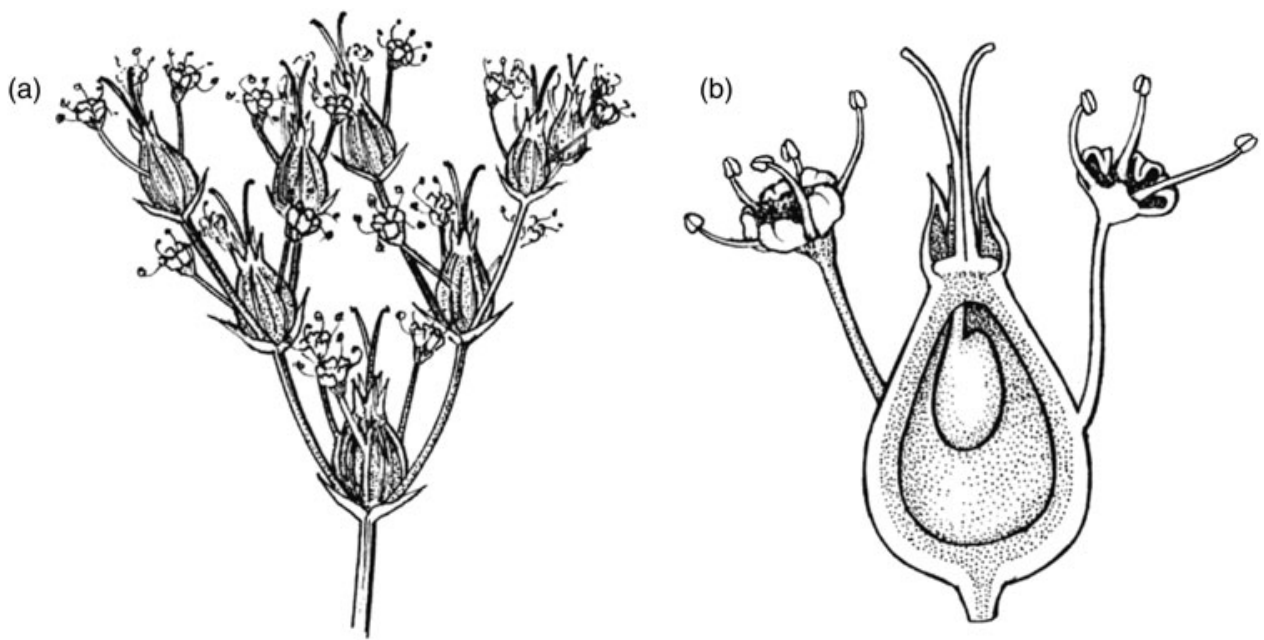

Figure 1. (a) Dichasial inflorescence of Petagnaea gussonei and (b) umbel of P. gussonei (Gianguzzi et al. 2004, modif.).

\section{Ovary anatomy}

The ovary consists of a one-layered epidermis (ca. $18 \mu \mathrm{m}$ ) with isodiametric, elongated, convex cells, slightly ornamented with a thin cuticle [Figure $3(\mathrm{~d}$, e)] and containing few anomocytic stomata (ca.
$20 \times \mathrm{mm}^{2}$ ); a multilayered chlorenchyma (usually 3-4 layers); and a reserve parenchyma [Figure 3(f,g, h)] that, associated with the ribs, encompasses medium-sized closed collateral vascular bundles, together with other smaller ones. Oil ducts (vittae) are adjacent, regardless of size, to vascular bundles;
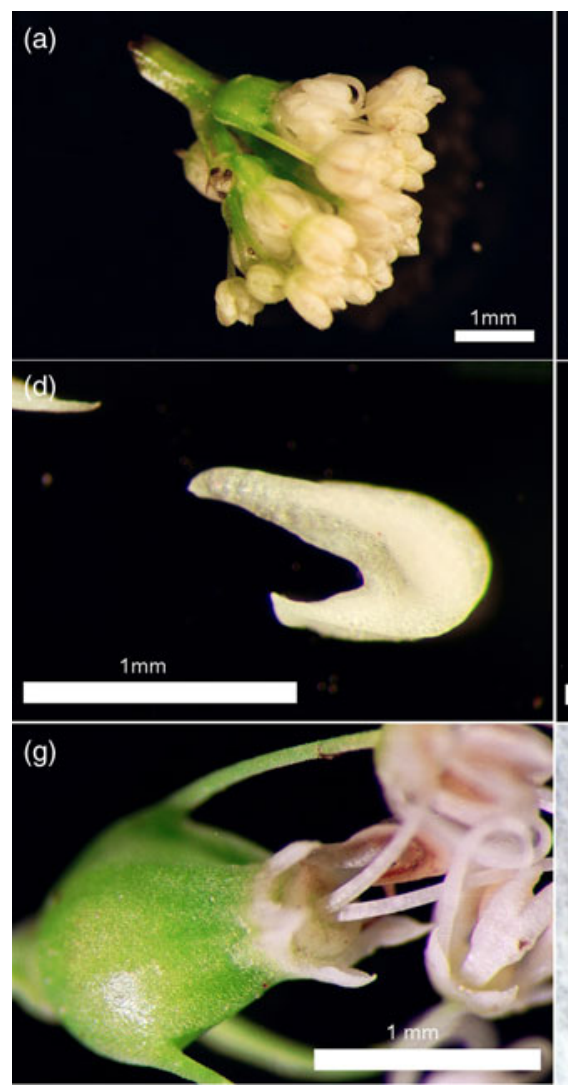
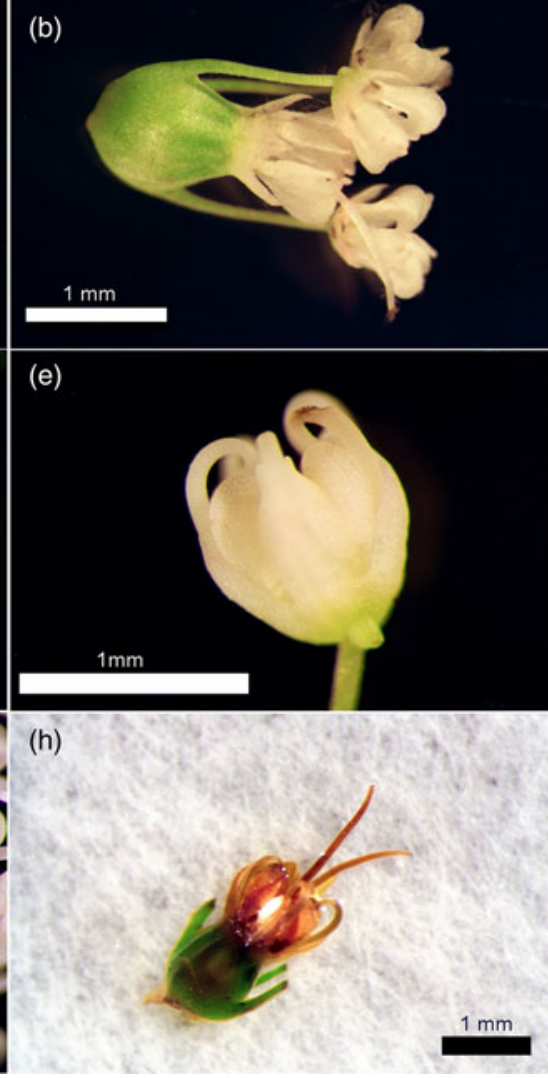
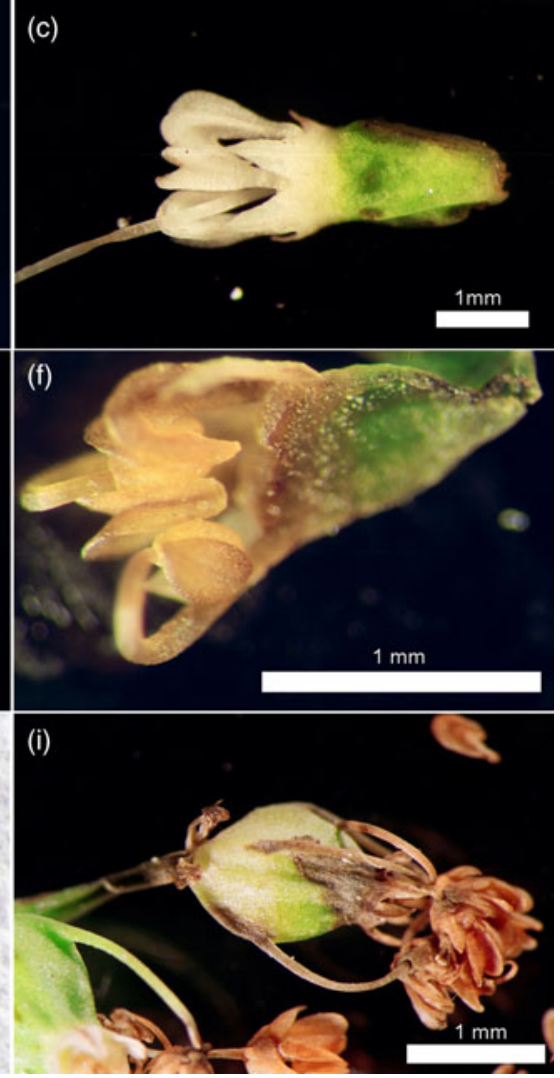

Figure 2. Flower morphology (stereo microscope images): (a) dichasial inflorescence; (b) umbel formed by three male flower pedicels fused to the ovary of a sessile hermaphrodite flower; (c) sepal and petal arrangement in a hermaphrodite flower with one style visible in the centre; (d) petal after removal with inflexed apex visible; (e) male flower with folded petals and anther filament; (f) longitudinal section showing keeled petals and stamens folded into the calyx tube; (g) view of the ovary, with inconspicuous ribs, calyx teeth, and the stylopodium, formed by two styles with septal glands at the base; (h) frontal view of a hermaphrodite flower with three male flower pedicels; and (i) mature ovary with senescent floral parts at the apex. Scale bars: $1 \mathrm{~mm}$. 


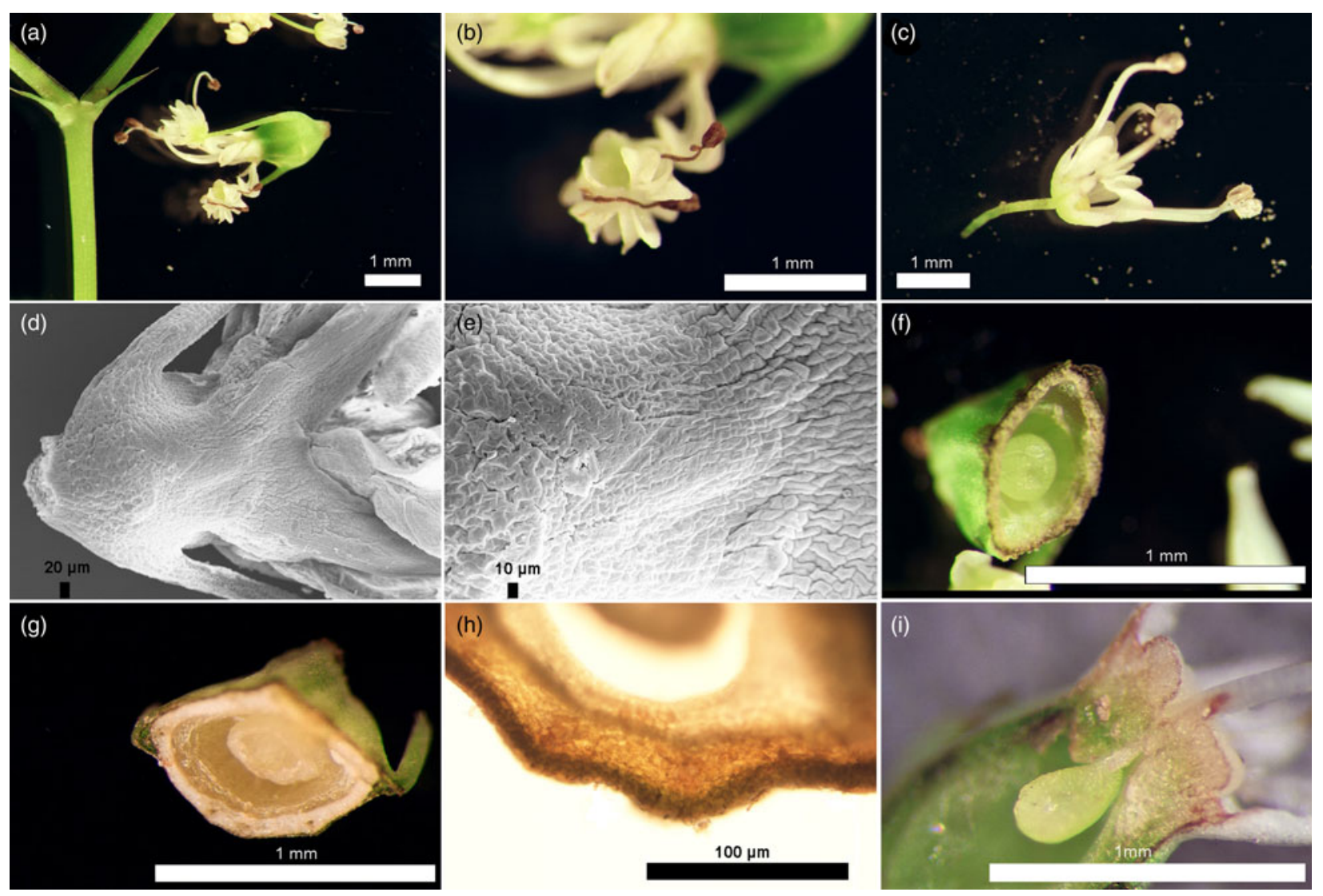

Figure 3. Flower morphology: (a) view of a pair of bracts of a dichasial inflorescence, and view of an umbel with hermaphrodite and male flowers (SM); (b,c) male flowers after pollen dispersal (SM); (d) ovary outer surface with male flower pedicels and sepals (SEM); (e) outer surface of ovary ribs (SEM); (f,g) detail of ovary central locule with a ripening ovule; ribs are visible in correspondence with staminal filaments (SM); (h) mature ovary transverse section showing external epidermis, chlorenchyma, reserve parenchyma, and jugal vittae (LM); and (i) details of ovule and funiculus $(S M)$. Scale bars: $a-b, c, f, g, i=1 \mathrm{~mm} ; \mathrm{d}=20 \mu \mathrm{m}$; $=10 \mu \mathrm{m}$; and $\mathrm{h}=100 \mu \mathrm{m}$.

oil ducts may also be independent. In the central part, an anatropous ovule connected to an evident funiculus is clearly visible [Figure 3(i)].

At ripening, the epidermis becomes a suberized waterproof exoderm. The chlorenchyma degenerates and both vascular bundles and reserve parenchyma turn into sclerenchyma, with formation of rare calcium-oxalate crystals, which make the fruit turn hard. The medullary parenchyma also degenerates, causing the formation of a large cavity in which the single seed develops. Under the SEM, a pear-shaped ovule is visible [Figure $4(\mathrm{a}, \mathrm{b})$ ], fully occupying the achene cavity, in which an evident honeycomb structure represents placenta residues.

\section{Micromorphology and anatomy of floral parts}

Sepals have a dorsal rib that extends into the ovary main ribs. The outer surface is composed of irregular cells, and shows a marked convexity forming a ridge along the sepal mid-axis; rare anomocytic stomata are present [Figure $4(\mathrm{c})$ ]. In the rib, cells become less convex, highly elongated and narrow, arranged in staggered parallel rows [Figure 4(d)]. The heartshaped petals of both flower types (i.e. male and hermaphrodite) are perfectly wedged in sepals with their enlarged part facing outward [Figure 4(e)], while a wide, thickened concavity is turned inward and inserted inside the thalamus at the apex [Figure 4 (f)]. Petals are composed of convex isodiametric epidermal cells with a strongly lobed outline. The epidermal cells of both petals and sepals are covered by epicuticular wax of the "rods or threads" type (see Wilkinson 1979), most evident at the suture lines [Figure $4(\mathrm{~g}, \mathrm{~h})$ ]. In the middle part of the petal, there are traces of vascular bundles constituted by narrow, elongated, thickened cells [Figure 4(i)]. Pedicels appear strongly papillose [Figure $4(1, \mathrm{~m})$ ], due to the presence of isodiametric cells with a weakly sinuous outline; epidermal cells generally show a very protruding papilla in their central part; besides these cells, other rectangular shaped cells are present, which subtend the vascular bundles within the pedicel [Figure 4(n)]. SEM of flower buds after clarification [Figure $4(\mathrm{o}, \mathrm{p})$ ] shows the spatial arrangement of first and second whorl and, at 

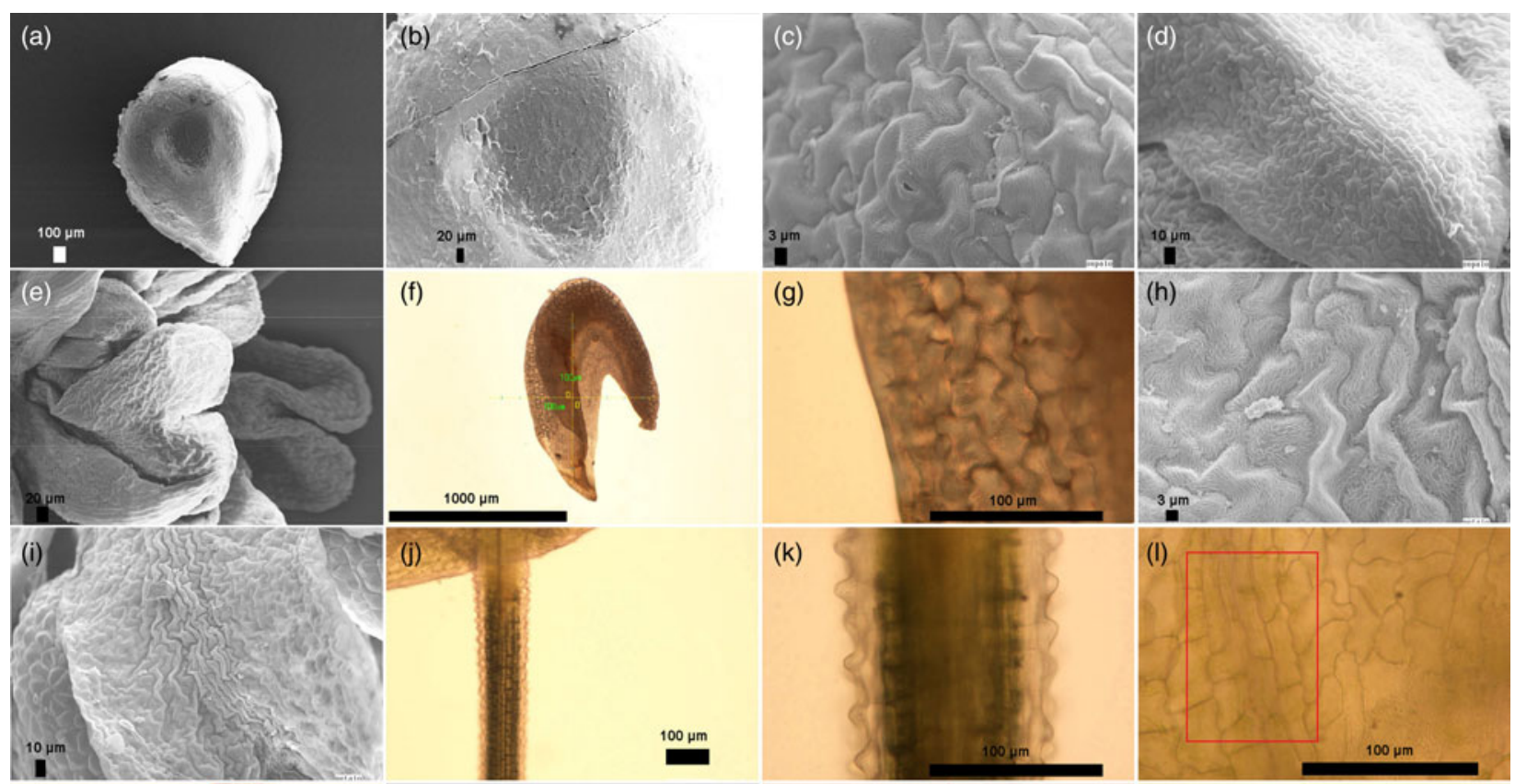

(g)
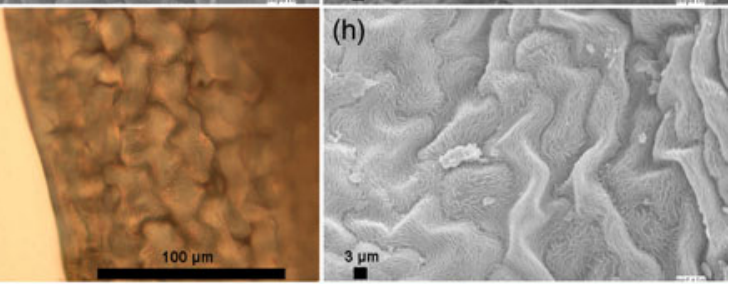

$(\mathrm{m})$
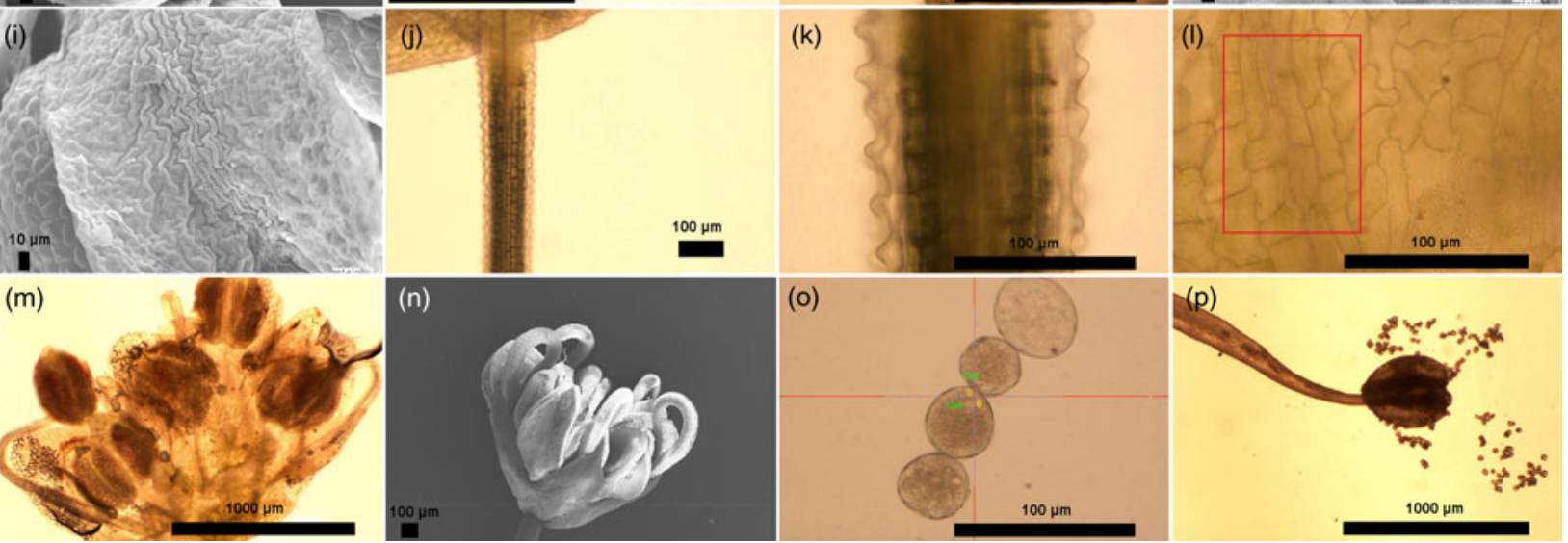

Figure 4. Flower micromorphology and anatomy: (a) ovule (SEM); (b) details of the achene cavity with inserted placenta (SEM); (c) sepal epidermal cells of a male flower with characteristic cuticular ornamentation (SEM); (d) the sepal outer surface of a male flower with midrib (SEM); (e) petal and sepal of a hermaphrodite flower (SEM); (f) male flower petal after clarification (LM); (g) petal epidermal cells of a male flower after clarification (LM); (h) petal epidermal cells of a male flower (SEM); (i) traces of vascular bundles on the petal adaxial surface of a male flower (SEM); (j) external morphology of male flower pedicels with external papillae after clarification (LM); (k) details of clarified papillae (LM); (1) epidermal cells and traces of vascular bundles (inside the square) (LM); (m) clarified male flower bud: details of filaments, anthers, and pollen sacs (LM); (n) male flower bud with petals, anthers, and curved staminal filaments (SEM); (o) pollen (LM); and (p) filament, anthers, and longitudinally dehiscent thecae after clarification (LM). Scale bars: a, g, j, k, n, o, p, $q=100 \mu \mathrm{m}$; b, e = 20 $\mu \mathrm{m}$; c, $h=3 \mu \mathrm{m} ; \mathrm{d}, \mathrm{i}=10 \mu \mathrm{m}$; and $\mathrm{f}, \mathrm{m}, \mathrm{p}, \mathrm{r}=1000 \mu \mathrm{m}$.

dehiscence of anthers, the spherically shaped ripening pollen grains [Figure $4(\mathrm{q}, \mathrm{r})]$. In transverse section, flower pedicels show a "U" profile and contain an arc of different sized vascular bundles within the aerenchyma; two collenchyma ridges surround the peduncle with an evident mechanical function. The staminal filament of both flowers (i.e. male and hermaphrodite) is constituted by slightly convex, square or rectangular cells [Figure 5(a,b,c,d)]; cuticular ornamentations are always "rods or threads" type, but oriented in a parallel and sinuous manner such as those of the anthers [Figure 5(e)] and can barely be seen, except in the sutures between contiguous cells where they are instead very deep [Figure $5(f, g, h)]$. The stigma is papillose and composed of very convex, rounded and slightly protruding cells, with the same cuticular ornamentation pattern as that of staminal filaments and anthers, but with a random arrangement. In the centre of this group of stigmatic cells a pore is present [Figure 5(i)].

\section{Fruit morphology}

The fruit is an obovate, glabrous, dark brown achene, $2-5 \mathrm{~mm}$ in diameter, provided with less ribs than the ovule (ca. 8), due to the tension induced by sclerification of inner tissues, two ribs being more evident than the other ones [Figure 6(a)]. SEM microphotographs evidenced marked ribs, which continue until the dorsal surface of the sepals [Figure 7(a)] mixed to the male flower pedicels; these ribs are due to the occurrence of elongated cells with numerous papillae, which make the peduncle surface very scarious [Figure 7(b)]. Continuing in acropetal direction, pedicels expand and become more papillose. The surface of the fruit shows ribs and intercostal spaces [Figure 7(c)], the ribs with narrow cells arranged in parallel rows, while the furrows have cells that are shorter and rhomboidal [Figure 7(d)]. The achene basal surface has short, isodiametric, and rhomboidal epidermal cells, with 


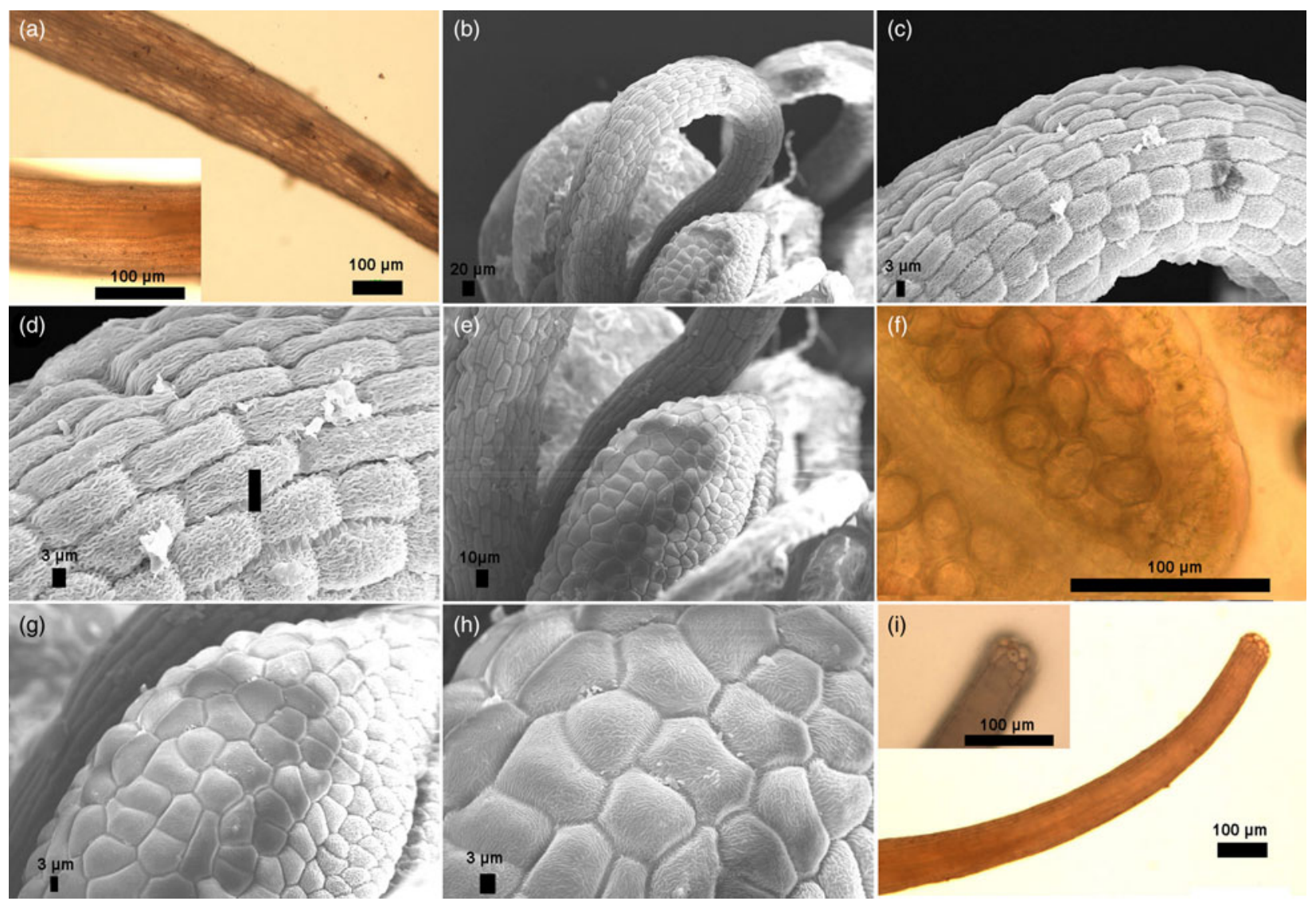

Figure 5. Flower micromorphology and anatomy: (a) staminal filament of a male flower after clarification; notice epidermal cells and vascular bundle traces in the central part of the style (LM); (b) curved staminal filament (SEM); (c, d) epidermal surface of a staminal filament; notice dense epicuticular wax (SEM); (e, g) outer surface of pollen sac with a mosaic of polyhedral cells (SEM); (f) pollen grains within pollen sacs of a hermaphrodite flower, separated by connective tissue, after clarification (LM); (h) cuticular ornamentation of anther epidermal cells (SEM); and (i) terminal portion of style and stigma from a hermaphrodite flower; notice the papillose stigmatic cells with pore (LM). Scale bars: $a, f, i=100 \mu \mathrm{m} ; \mathrm{b}=20 \mu \mathrm{m} ; \mathrm{c}, \mathrm{d}, \mathrm{g}, \mathrm{h}=3 \mu \mathrm{m}$; and $\mathrm{e}=10 \mu \mathrm{m}$.

marked cuticular ornamentations providing a reticulate pattern. The sepal outer surface is composed of isodiametric to sinusoidal epidermal cells with small thickened cuticular ornamentations, barely discernible as they are covered by epicuticular wax [Figure 7(e)]. At ripening, the pericarp undergoes a suberization process, essential for becoming waterproof and floating; the mesocarp becomes more lignified and compact, with smaller vittae [Figure 7(f)]; the endocarp is formed by a mosaic of numerous parenchymatous refractile cells [Figure $7(\mathrm{~g})$ ]. The embryo shows two cotyledons distinguishable in transparency [Figure 6(f)]. Fruit longitudinal sections at SEM magnification show that exocarp and mesocarp are fused together [Figure $7(\mathrm{~h})$ ].

Thanks to our data, it is possible to perform an interesting comparison with another peculiar Saniculoideae species: Hacquetia epipactis (Scop.) DC., a rare geophyte of the European forest. In fact, the comparison of fruit transverse sections from H. epipactis (Karcz et al. 2008) and P. gussonei
[Figure 6(b,c)] shows different outlines, due to the smaller number of ribs and intercostal spaces in P. gussonei. Surface sculpturing of intercostal space is irregularly undulated, with cells in $P$. gussonei showing anticlinal parallel striae, while in $H$. epipactis striae are randomly oriented and converging in a central papilla. Toward the centre, the mesocarp is lignified in both species, but lignification is continuous and thick all around the fruit in P. gussonei, while it is plaque shaped in H. epipactis. The mesocarp also contains vascular bundles, which in P. gussonei are small and numerous, associated with both ribs and secretory intrajugal tubes (vittae), the latter are positioned both on the ribs and vallecula while in H. epipactis vascular bundles are fewer, and vittae are larger and well defined, and are positioned only on the ribs. Both species have a parenchymatous endocarp, with honeycomb structures containing protein bodies in $H$. epipactis, and dense starch granules in $P$. gussonei. Residue of sepals, staminal filaments, and male flower pedicels are converging at the top of the fruit [Figure $6(\mathrm{~d}, \mathrm{e})]$. 

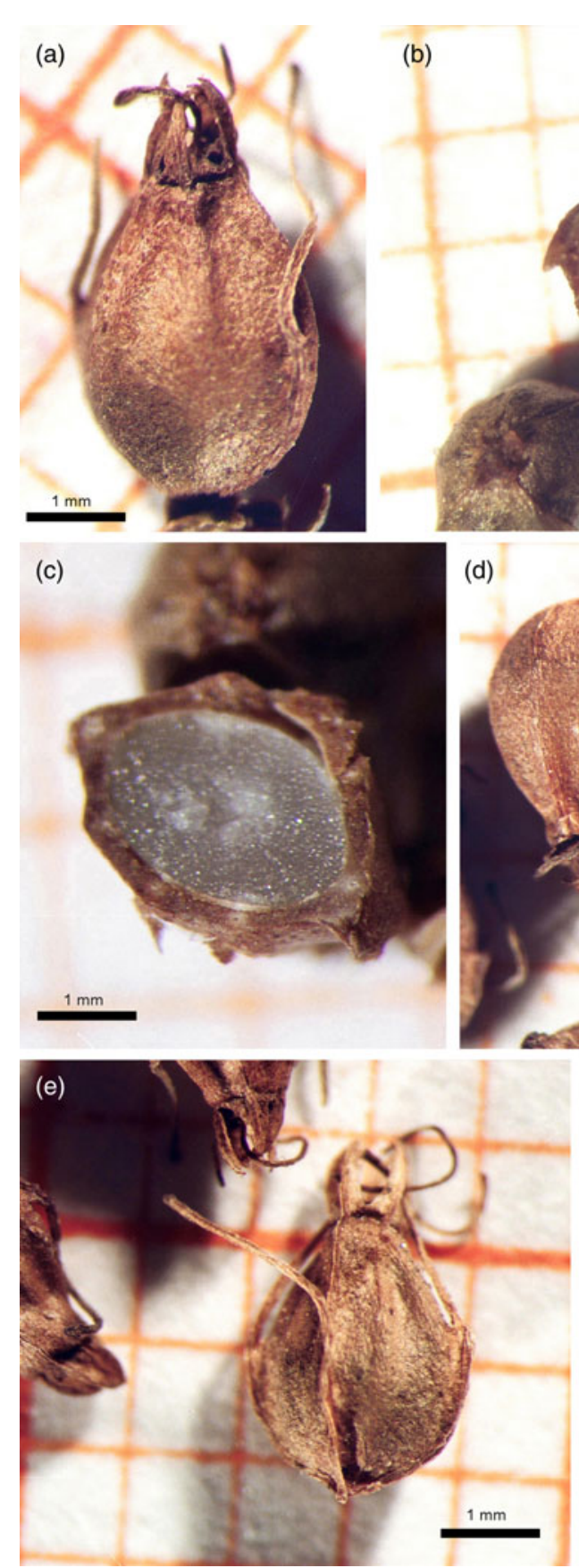

(d)
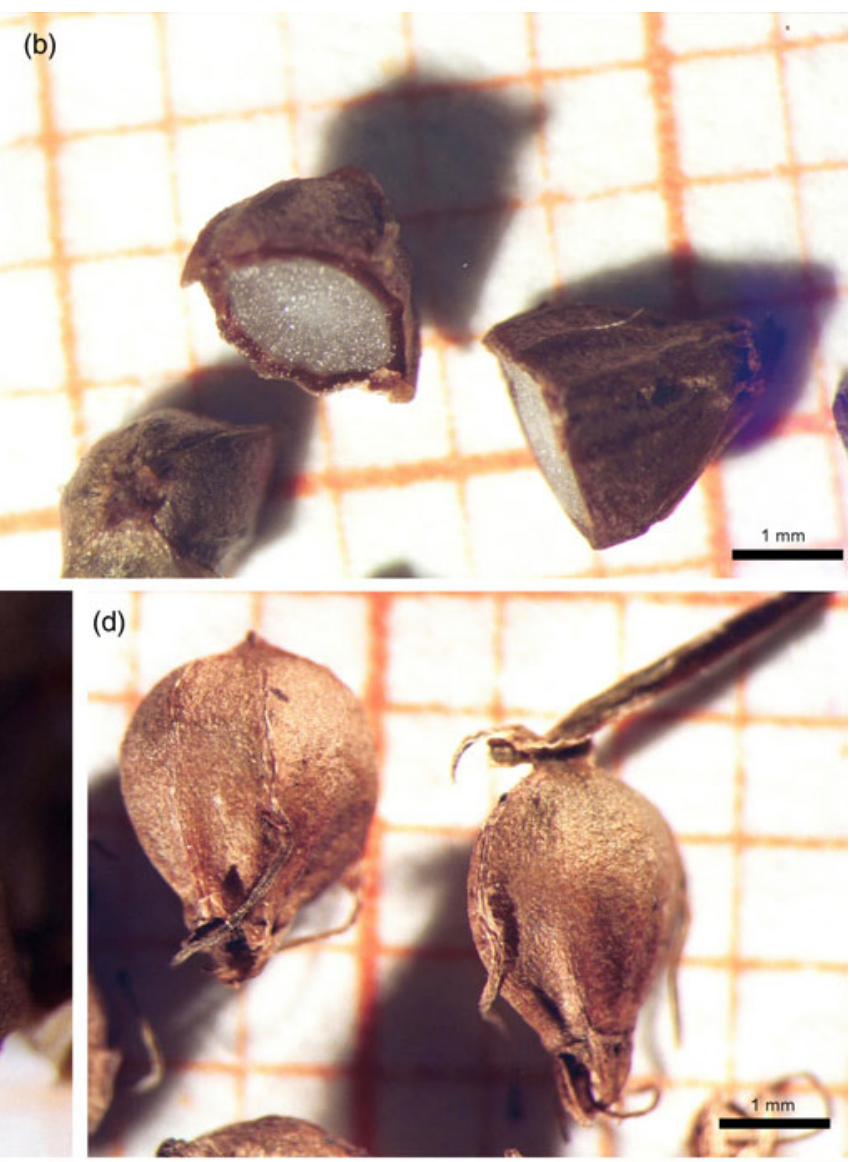

(f)

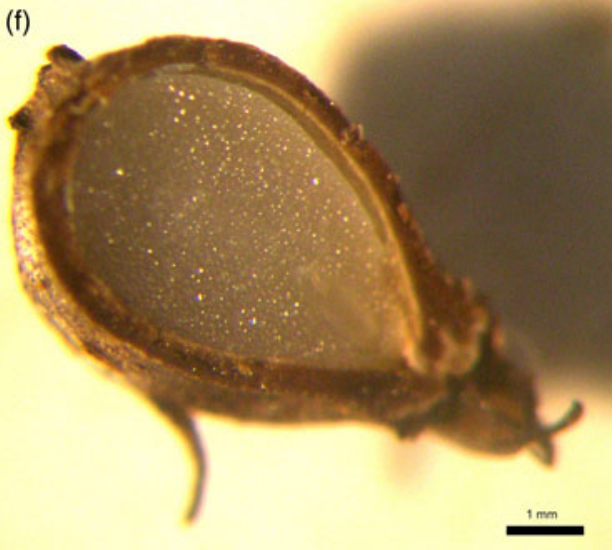

Figure 6. Fruit morphology (stereo microscope images): (a) dry fruit with male flower peduncles and residues of floral parts; (b) transverse section of mature achene and seed; (c) details of seed lignified outer tegument and parenchymatous reserves; (d, e) views of achenes, male flower peduncles, and residues of dried-flower; and (f) achene longitudinal section showing suberized exocarp, lignified mesocarp, parenchymatous endocarp, and seed with apical embryo and two cotyledons. Scale bars: $1 \mathrm{~mm}$.

\section{Discussion}

Exhaustive morphoanatomy studies using microscopy techniques (SM, LM and SEM) are scarce for the flower and fruit of Petagnaea. Although the study of Magin (1980) represents an important contribution to understanding the biology of this plant, some incongruences were detected through our present analyses. In fact, we were unable to confirm some of the phenomena reported by Magin, namely: (1) the presence of aberrant hermaphrodite flowers (i.e. exclusively male in the upper part of the plant and exclusively female in the rest of the plant); (2) the complex sexual inversion phenomena in male flowers (i.e. male flowers can become hermaphrodites or female); and (3) the appearance of the central hermaphrodite flower after the male flowers. Finally, Magin does not affirm directly that this plant has protandrous flowers. This phenomenon is only 

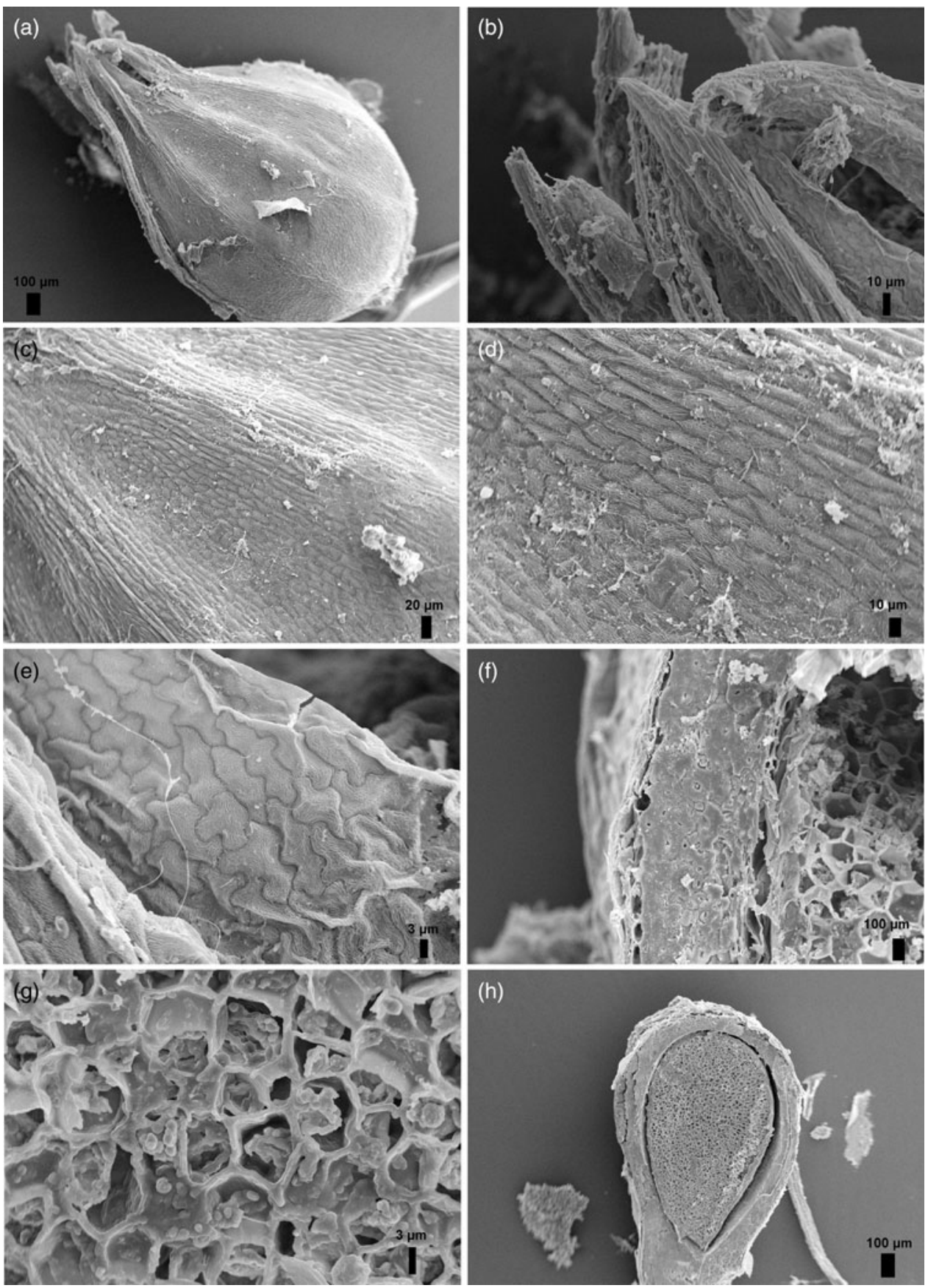

Figure 7. Fruit micromorphology (SEM): (a) achene exocarp with ribs, male flower peduncles, and dry calyx residue; (b) view of peduncles and sepals; (c) details of achene costal and intercostal spaces; (d) achene exocarp cells; (e) details of sepal sinuous epidermal cells; (f) sclereids in the achene mesocarp; $(\mathrm{g})$ details of seed parenchymal reserves; and $(\mathrm{h})$ transverse section of the dried fruit tegument. Scale bars: $\mathrm{a}, \mathrm{f}$, $\mathrm{h}=100 \mu \mathrm{m} ; \mathrm{b}, \mathrm{d}=10 \mu \mathrm{m} ; \mathrm{c}=20 \mu \mathrm{m} ; \mathrm{e}, \mathrm{g}=3 \mu \mathrm{m}$.

mentioned by Scharhag \& Claßen-Bockhoff (2008): "Astrantia major is multicyclic proterandrous and extremely dichogamous while Petagnaea gussonei is also protandrous, but flowers in a duodichogamous manner with a strong tendency to geitonogamy".

In this study, we observed that the hermaphrodite flower of $P$. gussonei is protandrous with an early loss of the three stamens. When the stamens are mature in the hermaphrodite flower, the ovary is still immature because it has not completed the ripening of the gametophyte, and thus self-fertilization within the same umbel is not possible. However, selffertilization is possible if another hermaphrodite flower of the same plant has already developed a mature ovule. Outcrossing may also be possible, with pollen from one plant fertilizing other plants. Our observations suggest that geitonogamy and autogamy could be mechanisms in the breeding system of 
P. gussone $i$ as found in other Apiaceae (Bell 1971; Jury 1996). However, the genetic data of $P$. gussonei populations previously reported (De Castro et al. 2013) indirectly indicate that, although these phenomena (i.e. geitonogamy and autogamy) are possible in Petagnaea, they could not be at the base of its present breeding system because of a predominance of vegetative reproduction. In fact, the genetic indexes obtained from isolated populations (e.g. low inbreeding coefficient, good genetic variability), the absence of gene flow of pollen among populations, and the very low germination show that this plant prefers a vegetative reproduction (propagation by stolons), which blocked its genetic variability over time (for further details, see De Castro et al. 2013).

The complex inversion phenomena documented by Magin (1980; see earlier) were not observed through our analysis, and this incompatibility might by related to the sampling carried out by Magin. It is not clear how many flowers or plants were studied by Magin (1980), but his observations were based on plant material cultivated at the Botanical Garden of Aachen (Germany) where different abiotic conditions could have stressed the plants, resulting in the development of aberrant flowers, which are normally not found in wild plants.

Based on fruit structure, several mechanisms can be proposed for the dispersal of Petagnaea fruit. All achenes present residues of staminal filaments and calyx teeth, which could constitute a precarious grip for epizoochory [Figure $6(\mathrm{~d}, \mathrm{e})$ ], whereas their light weight $(<0.3 \mathrm{mg})$ allows for the dispersal on animalcoats. Tackenberg et al. (2006) reported that species with diaspore mass $<2 \mathrm{mg}$ had a fair chance to be dispersed in curly wool as well as in straight hair over long distances, once they get attached to the animalcoat. In addition, the nature of Petagnaea achenes (i.e. woody mesocarp and parenchymatous endocarp) and the habitat of the plant (i.e. meso-hydric environments) suggest that the fruit could also float and disperse along rivulets (hydrochory). According to both the literature and our data (Jury 1996; De Castro et al. 2013), we suggest that both epizoochory and hydrochory are important in the fruit dispersal of this plant. In fact, according to the chloroplast genetic data reported by De Castro et al. (2013), no phylogeographic structure of two haplotypes was detected among the populations that also correlated with a distribution by the stream and/or rivulets (see Figure 2 in De Castro et al. 2013). This pattern can only be explained by supposing that epizoochory also represents an important mechanism for fruit dispersal. Thus, considering these genetic data and the achene microstructure, we believe that fruit dispersal by animals has been fundamental in the distribution of this species.

\section{Acknowledgements}

We gratefully acknowledge the anonymous reviewer for his/her helpful suggestions, which greatly improved the quality of the article. Special thanks go to Prof. Cristina Salmeri (University of Palermo, Dept. STEBICEF, Italy) for her helpful suggestions and to Nando Peretti Foundation for allowing us to study this plant in the previous years (Project 200715).

\section{References}

Baillon HE. 1880. Historie des Plantes. Vol. 7. Paris: Librairie Achette [Petagnaea in pp. 149-150].

Beccari N, Mazzi V. 1966. Manuale di tecnica microscopica. VI edizione, Società Editrice Libraria: Milano.

Bell CR. 1971. Breeding systems and floral biology of the Umbelliferae or evidence for specialization in unspecialized flowers. In: Heywood VH, editor. The Biology and Chemistry of the Umbelliferae. London: Academic Press. pp. 93-105.

Bertoloni A. 1837. Flora italica sistens plantas in Italia et in insulsi circumstantibus sponte nascentes. Vol. 3. Masi: Bologna [Petagnaea in pp. 119-120].

Calviño CI, Downie SR. 2007. Circumscription and phylogeny of Apiaceae subfamily Saniculoideae based on chloroplast DNA sequences. Mol Phylogenet Evol 44: 175-191.

Calviño CI, Martıñez SG, Downie SR. 2008. Morphology and biogeography of Apiaceae subfamily Saniculoideae as inferred by phylogenetic analysis of molecular data. Am J Bot 95(2): 196-214.

Caruel T. 1889. Flora Italiana. Vol. 8. Tipografia Le Monnier: Firenze [Petagnaea in pp. 199-201].

Catalano G. Francesco Vallardi 1925. Guida pratica di anatomia e fisiologia vegetale. Dott. Francesco Vallardi: Milano.

Colombo P. 2003. Preparati microscopici di botanica. Napoli: EdiSES.

Colombo P, Melati MR, Scialabba A, Raimondo FM. 1997. Comparative anatomy and development in Petagnaea, Lereschia, and Sanicula (Umbelliferae). Bocconea 5(2): 613-618.

De Castro O, Cennamo P, De Luca P. 2009. Analysis of the genus Petagnaea Caruel (Apiaceae), using new molecular and literature data. Plant Syst Evol 278: 239-249.

De Castro O, Gianguzzi L, Colombo P, De Luca P, Marino G, Guida M. 2007. Multivariate analysis of sites using water invertebrates and land use as indicators of the quality of biotopes of Mediterranean relic plant (Petagnaea gussonei, Apiaceae). Environ Bioind 2(3): 161-171.

De Castro O, Marino G, Gianguzzi L, Guida M. 2006. A survey on conservation status of Petagnaea gussonei (Apiaceae), an endemic species to Nebrodi mountains (Sicily, Italy). Delpinoa 48: $11-19$.

De Castro O, Senatore F, Rigano D, Formisano C, Cennamo P, Gianguzzi L. 2008. Composition of the essential oil of Petagnaea gussonei (Sprengel) Rauschert, a relict species from Sicily (Southern Italy). Flav Fragr J 23: 172-177.

De Castro O, Sepe F, Di Maio A, Cennamo P, De Luca P, Gianguzzi L, et al. 2013. Genetic structure in the paleoendemic and endangered Petagnaea gussonei (Spreng.) Rauschert (Saniculoideae, Apiaceae) and implications for its conservation. Plant Syst Evol 299: 209-223.

Drude CGO. 1898. Umbelliferae. In: Engler A, Prantl K, editors. Die Natürrlichen Pflanzenfamilien III. Leipzig: Wilhelm Engelmann [Petagnaea in pp. 144-145].

Esau K. 1965. Plant anatomy. New York: Wiley. 
Froebe HA. 1964. Die Blütenstande der Saniculoideen (Umbelliferae). Eine vergleichend-morphologische und entwicklungsgeschichtliche Untersuchungen. Beitraege zur Biologie der Pflanzen 40: 325-388.

Fuchs C. 1963. Fuchsin staining with $\mathrm{NaOH}$ clearing for lignified elements of whole plants or plants organs. Stain Technol 38: $141-144$.

Gianguzzi L, La Mantia A. 2006. Petagnaea gussonei. The IUCN Red List of Threatened Species. Version 2014.2. Available: http://www.iucnredlist.org/details/61616/0. Accessed on 14 Jan 2015.

Gianguzzi L, La Mantia A, Lo Presti RM. 2004. Distribuzione, Ecologia e Status conservativo di Petagnaea gussonei (Sprengel) Rauschert (Apiaceae). Nat Sicil 19(1(S4)): 205-242.

Gianguzzi L. 2002. Osservazioni sulla Conservazione in situ del popolamento di Petagnaea gussonei (Spreng.) Rauschert, paleoendemita esclusivo dei Monti Nebrodi (Sicilia nordorientale). Inform Bot Ital 34(1): 63-69.

Gianguzzi L. 2011. Petagnaea gussonei (Sprengel) Rauschert. Inform Bot Ital 43(2): 381-458.

Gussone G. 1827. Florae Siculae Prodromus sive plantarum in Siciliae ulteriori nascentium enumeratio secundum systema Linneanum disposita. I suppl. Napoli: Ex Regia Typographia, [Petagnaea in p. 311].

Huttunen S, Laine K. 1983. Effects of air-borne pollutants on the surface wax structure of Pinus sylvestris needles. Ann Bot Fenn 20: 79-86.

Jensen WA. 1962. Botanical histochemistry principles and practice. London: W. H. Freeman and Co.

Johansen DA. 1940. Plant microtechnique. New York: McGrawHill.

Jury SL. 1996. Pollination and dispersal in Mediterranean umbellifers. Bocconea 5: 193-199.

Kadereit JW, Repplinger M, Schmalz N, Uhink CH, Wörz A. 2008. The phylogeny and biogeography of Apiaceae subf. Saniculoideae tribe Saniculeae: from south to north and south again. Taxon 57: 365-382.
Karcz J, Burczyk J, Zych M, Stolarczyk A, Terminska-Pabis K, Banas A, et al. 2008. Structure and phytochemistry of the fruit of Hacquetia epipactis (Scop.) DC. (Saniculoideae, Apiaceae). Acta Biol Cracov 50((S1)): 49. Available: http://www.semlab. us.edu.pl/pdf/hacquetia.pdf. Accessed 14 Jan 2015.

Kronister J. 2013. Die Infloreszenzentwicklung der Saniculoideae, Apiaceae. Diploma thesis. Available: http://othes.univie.ac.at/ 29291/1/2013-08-12_0106534.pdf. Accessed on 14 January 2015 Austria: University of Vienna.

Liu M. 2004. A taxonomic evaluation of fruit structure in the family Apiaceae. [Ph.D. dissertation]. Available: https://ujdigispace.uj.ac.za/handle/10210/239. Accessed on 14 January 2015. Johannesburg, South Africa: Rand Afrikaans University.

Liu M, van Wyk B-E, Tilney PM. 2003. The taxonomic value of fruit structure in the subfamily Saniculoideae and related African genera (Apiaceae). Taxon 52: 261-270.

Magin N. 1980. Eine blutenmorphologische analyse der Lagoecieae (Apiaceae). Plant Syst Evol 133(3-4): 239-259.

Perrone R, De Rosa P, De Castro O, Colombo P. 2013. A further analysis of secretory structures of some taxa belonging to the genus Hypericum (Clusiaceae) in relation to the leaf vascular pattern. Turk J Bot 37: 847-858.

Sass JE. 1958. Botanical microtechnique. Ames Iowa: The Iowa StateUniversity Press.

Scharhag C, Claßen-Bockhoff R. 2008. Architecture and flowering sequence in the Apiaceae-Saniculoideae. In: Gradstein SR, Klatt S, Normann F, Weigelt P, Willmann R, Wilson R, editors. Systematics. Göttingen: Universitätsverlag Göttingen.

Tackenberg O, Römermann C, Thompson K, Poschlod P. 2006. What does diaspore morphology tell us about external animal dispersal? Evidence from standardized experiments measuring seed retention on animal-coats. Basic Appl Ecol 7(1): 45-58.

Wilkinson HP. 1979. The plant surface (mainly leaf). In: Metcalfe CR, Chalk L, editors. Anatomy of the dicotyledons. 2nd edn, Oxford: Clarendon Press. pp. 97-165.

Wolff H. 1913. Umbelliferae-Saniculoideae. In: Engler A, editor. Das Pflanzenreich IV, 228 (Hf. 61). Leipzig: Wilhelm Engelmann. pp. 273-274 [Petagnaea in pp. 23, 273-274]. 